double bond with osmium tetroxide. ${ }^{8}$ The mass spectrum of the silylated compound is shown in Fig. 2, and is analogous to the spectrum of the derivative of the 18-carbon homologue. ${ }^{9}$ The allylic double bond (Fig. 2) is indicated by fragments at $m / e 229$ and 331 . The peak at $m / e 159$ is the base peak from the 18-carbon derivative and is probably derived from a three carbon unit including carbon atoms 3 and 4 (original allylic portion). This peak is absent when the hydroxylated double bond is in a non-allylic position. ${ }^{9}$ The peak at $m / e 313$ is present with a similar intensity in the spectrum of the 18-carbon derivative and therefore probably originates from the polar portion. Other fragments are indicated in Fig. 2.

The present work is part of the project "Structure and Function of Membrane Lipids", supported by a grant from The Tri-Centennial Fund of the Bank of Sweden. The authors thank Karin Nilsson for important assistance, and Anders Lilja and Hakon Leffler for collecting the honey bees.

1. Morrison, W. R. Biochim. Biophys. Acta 176 (1969) 537.

2. Moscatelli, E. A. and Gilliland, K. M. Lipids 4 (1969) 244.

3. Panganamala, R. V., Geer, J. C. and Cornwell, D. G. J. Lipid Res. 10 (1969) 445.

4. Bieber, L. L., O'Connor, J. D. and Sweeley, C. C. Biochim. Biophys. Acta 187 (1969) 157.

5. Karlsson, K.-A. Acta Chem. Scand. 22 (1968) 3050.

6. Karlsson, K.-A. Nature 188 (1960) 312.

7. Karlsson, K.-A. Acta Chem. Scand. 19 (1965) 2425.

8. Niehaus, Jr., W. G. and Ryhage, R. Anal. Chem. 40 (1968) 1840.

9. Karlsson, K.-A. To be printed in Proceedings from a Symposium on Chemistry and Metabolism of Sphingolipids, held at Michigan State University, East Lansing, U.S.A., May 5 and 6, 1969 .

Received November 15, 1969.

Acta Chem. Scand. 23 (1969) No. 10

\section{Phase Relations in the System $\mathrm{Ni}-\mathrm{S}-\mathrm{Se}$ at $500^{\circ} \mathrm{C}$}

\author{
KJELL HAUGSTEN and ERLING RøST \\ Kjemisk Institutt A, Universitetet $i$ Oslo, \\ Blindern, Oslo 3, Norway
}

$T$

he phase relations at $500^{\circ} \mathrm{C}$ of the ternary system Ni-S-Se have been examined by $\mathrm{X}$-rays and metallographic methods. The alloys were prepared by melting calculated amounts of the elements in evacuated silica tubes. The samples were then annealed for about a week at $500^{\circ} \mathrm{C}$ and quenched in water. 65 samples were synthesized for this investigation.

No isolated ternary phase was found at $500^{\circ} \mathrm{C}$. However, in the phases existing in the binary systems, Ni-S and Ni-Se, complete mutual interchange of sulfur and selenium is possible.

In the phase $\mathrm{Ni}_{3}(\mathrm{~S}, \mathrm{Se})_{2}$ with rhombohedral structure, the successive replacement of sulfur by selenium is accompanied by an increase of the lattice dimensions, linear to the S/Se-ratio; see Table $1 a$. The rhombohedral angle is less than $90^{\circ}$ in the sulfur-rich and greater than $90^{\circ}$ in the selenium-rich compounds. No variation from the stoichiometric composition $\mathrm{Ni}_{3}(\mathrm{~S}, \mathrm{Se})_{2}$ could be observed.

$A$ phase $\mathrm{Ni}_{6} \mathrm{~S}_{5}$ with orthorhombic structure was first found by Lundqvist, ${ }^{1}$ and later confirmed by others. According to different authors, this phase is stable between approximately 400 and $570^{\circ} \mathrm{C}$. There are, however, some discrepancies concerning the composition of the phase. For instance, Kullerud and Yund ${ }^{2}$ report the stoichiometry to be $\mathrm{Ni}_{7} \mathrm{~S}_{6}$, whereas Rosenqvist ${ }^{3}$ found a small homogeneity range including both the compositions $\mathrm{Ni}_{6} \mathrm{~S}_{5}$ and $\mathrm{Ni}_{7} \mathrm{~S}_{6}$. A phase $\mathrm{Ni}_{6} \mathrm{Se}_{5}$, with orthorhombic crystal structure similar to that of the phase mentioned above, has been reported by Grønvold et al. ${ }^{4}$

In the present investigation samples of $\mathrm{Ni}_{6} \mathrm{~S}_{5}$ and $\mathrm{Ni}_{7} \mathrm{~S}_{6}$ contained two phases; one on either side of the orthorhombic phase, whereas a sample with composition $\mathrm{Ni}_{5.87} \mathrm{~S}_{5}$ appeared to contain this phase only. (The notation $\mathrm{Ni}_{x} \mathrm{~S}_{5}$ is used in this paper for reasons given below). No variation of the lattice constants of the orthorhombic phase could be observed in these samples and therefore variation of the $\mathrm{Ni} / \mathrm{S}$ ratio is assumed to be negligible. 
Table 1. Lattice constants (in $\AA$ ) of Ni-S-Se compounds.

a)

\begin{tabular}{|c|c|c|}
\hline Rhombohedral & $a$ & angle $\alpha$ \\
\hline $\mathrm{Ni}_{3} \mathrm{~S}_{2}$ & 4.082 & $89.46^{\circ}$ \\
\hline $\mathrm{Ni}_{3}\left(\mathrm{~S}_{.75} \mathrm{Se}_{.25}\right)_{2}$ & 4.121 & $89.83^{\circ}$ \\
\hline $\mathrm{Ni}_{3}\left(\mathrm{~S}_{.625} \mathrm{Se}_{.375}\right)_{2}$ & 4.1405 & $90.00^{\circ}$ \\
\hline $\mathrm{Ni}_{3}\left(\mathrm{~S}_{.50} \mathrm{Se}{ }_{.50}\right)_{2}$ & 4.160 & $90.17^{\circ}$ \\
\hline $\mathrm{Ni}_{3}\left(\mathrm{~S}_{.25} \mathrm{Se}_{.75}\right)_{2}$ & 4.204 & $90.46^{\circ}$ \\
\hline $\mathrm{Ni}_{3} \mathrm{Se}_{2}$ & 4.237 & $90.70^{\circ}$ \\
\hline
\end{tabular}

b)

$\begin{array}{lccc}\text { Orthorhombic } & a & b & c \\ \mathrm{Ni}_{5.730}\left(\mathrm{~S}_{.5} \mathrm{Se}_{.5}\right)_{5}{ }^{a} & 3.342 & 11.612 & 16.62 \\ \mathrm{Ni}_{5.926}\left(\mathrm{~S}_{.5} \mathrm{Se}_{.5}\right)_{5} & 3.345 & 11.618 & 16.64 \\ \mathrm{Ni}_{6}\left(\mathrm{~S}_{.5} \mathrm{Se}_{.5}\right)_{5} & 3.351 & 11.634 & 16.66 \\ \mathrm{Ni}_{6.072}\left(\mathrm{~S}_{.5} \mathrm{Se}_{.5}\right)_{5} & 3.359 & 11.649 & 16.68 \\ \mathrm{Ni}_{6_{6.246}}\left(\mathrm{~S}_{.5} \mathrm{Se}_{.5}\right)_{5}{ }^{a} & 3.364 & 11.662 & 16.68\end{array}$

c)

$\begin{array}{llll}\mathrm{Ni}_{5.87} \mathrm{~S}_{5} & 3.254 & 11.338 & 16.43 \\ \mathrm{Ni}_{5.87}\left(\mathrm{~S}_{.89} \mathrm{Se}{ }_{.11}\right)_{5} & 3.290 & 11.410 & 16.43 \\ \mathrm{Ni}_{6}\left(\mathrm{~S}_{.75} \mathrm{Se}_{.25}\right)_{5} & 3.316 & 11.514 & 16.54 \\ \mathrm{Ni}_{6}\left(\mathrm{~S}_{.50} \mathrm{Se}{ }_{.50}\right)_{5} & 3.351 & 11.634 & 16.66 \\ \mathrm{Ni}_{6}\left(\mathrm{~S}_{.25} \mathrm{Se}_{.75}\right)_{5} & 3.393 & 11.757 & 16.83 \\ \mathrm{Ni}_{6} \mathrm{Se}_{5} & 3.437 & 11.858 & 17.06\end{array}$

d)

$\begin{array}{lcc}\text { Hexagonal } & a & c \\ \mathrm{Ni}_{.50} \mathrm{~S}_{.50} & 3.439 & 5.352 \\ \mathrm{Ni}_{.50} \mathrm{~S}_{.13} \mathrm{Se}_{.37}{ }^{a} & 3.492 & 5.358 \\ \mathrm{Ni}_{.50} \mathrm{~S}_{.25} \mathrm{Se}_{.25}{ }^{a} & 3.555 & 5.361 \\ \mathrm{Ni}_{.50} \mathrm{~S}_{.37} \mathrm{Se}_{.13}{ }^{a} & 3.612 & 5.360 \\ \mathrm{Ni}^{.50} \mathrm{Se}_{.50}{ }^{a} & 3.662 & 5.357\end{array}$

a Two phase samples.

In the ternary region, however, a certain variation of the nickel-chalcogen ratio is possible. This variation was examined for samples containing equal parts of sulfur and selenium, and the observed lattice constants are given in Table $1 b$. On the basis of these values the homogeneity range was found to extend from $\mathrm{Ni}_{5.9}\left(\mathrm{~S}_{.5} \mathrm{Se}_{.5}\right)_{5}$ to $\mathrm{Ni}_{.612}\left(\mathrm{~S}_{.5} \mathrm{Se} .5\right)_{5}$.
Using a vacuum-pycnometric method the densities of three samples of the orthorhombic phase were determined to be:

$\begin{array}{ll}\mathrm{Ni}_{5.87} \mathrm{~S}_{5}, & d=5.49 \mathrm{~g} \mathrm{~cm}^{-1}, Z=3.97 \\ \mathrm{Ni}_{5.93}\left(\mathrm{~S}_{.5} \mathrm{Se}_{.5}\right)_{5}, & d=6.38 \mathrm{~g} \mathrm{~cm}^{-1}, Z=3.98 \\ \mathrm{Ni}_{6.07}\left(\mathrm{~S}_{.5} \mathrm{Se}_{.5}\right)_{5}, & d=6.43 \mathrm{~g} \mathrm{~cm}^{-1}, Z=3.99\end{array}$

Within experimental errors all these compounds contain 20 chalcogen atoms per unit cell, whereas a small variation of the nickel content is possible. Table $1 c$ shows lattice constants of the orthorhombic phase in samples with increasing $\mathrm{Se} / \mathrm{S}$ fraction, and, as can be seen, a smooth increase of the lattice constants was observed.

At about $500^{\circ} \mathrm{C}$ the hexagonal NiAs$(B 8-C 6)$ type structure has a range of homogeneity from 50.0 to 51.5 at. $\% \mathrm{~S}$ in the nickel-sulfur system, ${ }^{5}$ and from 50.5 to 56.5 at. $\%$ in the nickel-selenium system. ${ }^{6}$ When selenium is successively substituted for sulfur in samples along the nickel-rich limit of the phase, the $a$-axis increases considerably whereas the $c$-axis remains almost constant, as can be seen in Table $1 d$. At the chalcogen-rich limit of the phase the structure is hexagonal only for the most sulfur-rich samples, and by increasing selenium content a monoclinic deformation takes place.

In the pyrite- $(C 2)$ type phase region $\mathrm{NiS}_{2}-\mathrm{NiSe}_{2}$, we observed a continuous linear increase of the lattice constants from 5.688 to $5.965 \AA$. This is in good agreement with the results given by Klemm.?

1. Lundqvist, D. Arkiv Kemi, Mineral. Geol. A 24 (1947) No. 21.

2. Kullerud, G. and Yund, R. A. Carnegie Inst. Wash., Yearb. 58 (1958/59) 139.

3. Rosenqvist, T. J. Iron Steel Inst. (London) 176 (1954) 37.

4. Grønvold, F., Møllerud, R. and Røst, E. Acta Chem. Scand. 20 (1966) 1997.

5. Laffitte, M. Bull. Soc. Chim. France 1959 1211.

6. Grønvold, F. and Jacobsen, E. Acta Chem. Scand. 10 (1956) 1440.

7. Klemm, D. D. Neues. Jahrb. Mineral. Monatsh. 196232.

Received October 27, 1969. 